\title{
Pengaruh Penerapan Kegiatan Keagamaan di Lembaga Pendidikan Formal Terhadap Peningkatan Kecerdasan Spiritual Anak
}

\section{A. Mustika Abidin ${ }^{*}$}

\author{
${ }^{1}$ UIN Alauddin Makassar
}

\section{ARTICLE INFO}

\section{ARTICLE HISTORY}

Received: 09 Okt. 2019

Revised: 09 Okt. 2019

Accepted: 09 Okt. 2019

\section{KEYWORDS}

penerapan kegiatan keagamaan; kecerdasan spritual anak; sopan santun; application of religious activities;

children's spiritual intelligence

\section{ABSTRACT}

Penelitian ini menunjukkan bahwa penerapan kegiatan keagamaan di lembaga pendidikan formal memberikan pengaruh terhadap peningkatan kecerdasan spiritual anak. Sebagaimana diketahui bahwa kegiatan keagamaan merupakan sistem kepercayaan dan peribadatan dimana seseorang bisa mengungkapkan dengan jelas secara lahiriah mengenai spiritualitasnya. Sehingga, seseorang yang memiliki agama yang baik atau hubungan yang kuat dengan Allah swt., akan memiliki kecerdasan spiritual yang baik pula sehingga akan berdampak pula kepada kepandaian orang tersebut dalam berinteraksi dengan manusia, karena dibantu oleh Allah yaitu hati manusia dijadikan cenderung kepada-Nya. Untuk itu, lingkungan sekolah yang merupakan lembaga formal juga mempengaruhi kecerdasan spiritual anak karena selain memperoleh pengetahuan, anak juga harus diberi contoh atau pemahaman akan perbuatan atau nilai. Jika guru memberi nilai kehidupan (ajaran keagamaan) yang baik untuk anak, maka akan membuat kecerdasan spiritual anak akan baik pula sehingga diharapkan anak mampu memaknai hidupnya dengan lebih baik.

This research shows that the application of religious activities in formal educational institutions has an influence on increasing children's spiritual intelligence. As it is known that religious activities are a system of beliefs and worship where a person can express clearly outwardly about his spirituality. So, someone who has a good religion or a strong relationship with God Almighty, will have a good spiritual intelligence so that it will also affect the intelligence of these people in interacting with humans, because it is assisted by God that human hearts are made inclined towards Him. For this reason, the school environment which is a formal institution also influences children's spiritual intelligence because in addition to gaining knowledge, children must also be given examples or understanding of their actions or values. If the teacher gives a good life value (religious teachings) for the child, it will make the children's spiritual intelligence will be good too so that the child is expected to be able to interpret his life better. 


\section{PENDAHULUAN}

Pendidikan adalah usaha sadar dan terencana untuk mewujudkan suasana belajar dan proses pembelajaran agar siswa secara aktif mengembangkan potensi dirinya untuk memiliki kekuatan spiritual keagamaan, pengendalian diri, kepribadian, kecerdasan, akhlak mulia serta keterampilan yang dimiliki dirinya, masyarakat, bangsa dan Negara. ${ }^{1}$

Pendidikan Agama Islam yang diajarkan pada setiap lembaga merupakan bagian pendidikan yang sangat penting bagi pembentukan kepribadian anak, sebagaimana diungkapkan oleh Zakiah Drajat bahwa pendidikan agama Islam bertujuan untuk membentuk kepribadian anak, sesuai dengan ajaran agama Islam. Dengan pendidikan akan menumbuhkan ilmu sehingga dengan ilmu akan memberikan ketentraman, dimana secara terminologis menurut Al-Qadhi 'Abd. al-Jabbar, ia menyatakan bahwa العلم يقتضى سكون العالم الى ماتنتاوله (ilmu adalah suatu makna yang dapat menentramkan hati bagi seorang alim terhadap apa yang telah dicapainya).

Di Era globalisasi, arus informasi semakin terbuka dan hampir tidak mempunyai sekat yang dapat membatasi untuk menyaring materi informasi. Kecenderungan tersebut juga ditunjang oleh laju perkembangan teknologi dan arus kehidupan global yang sulit atau tidak dapat dibendung lagi. Globalisasi memiliki dampak yang beragam bagi kehidupan umat manusia, bisa berdampak positif dan bisa juga negatif. Konteks ilmu pengetahuan dan teknologi, mungkin tidak dapat menghitung lagi keuntungan yang didapat darinya. Akan tetapi dalam konteks lain, misalnya budaya ataupun pendidikan, globalisasi ternyata berpotensi menggerus eksistensi dunia karena adanya sifat eksploitatif di dalamnya. ${ }^{4}$

Salah satu problem yang dihadapi masyarakat yang sedang dalam proses modernisasi adalah cara menempatkan nilai-nilai dan orientasi keagamaannya di tengah-tengah perubahan yang terus terjadi dengan cepat dalam kehidupan sosialnya. Di satu pihak ingin mengikuti gerak modernisasi dan menampilkan diri sebagai masyarakat modern, akan tetapi di lain pihak tidak ingin kehilangan ciri-ciri kepribadiannya yang ditandai dengan berbagai macam nilai yang telah dianutnya. Dalam transisi seperti ini, kerap kali ingin meninggalkan segala sistem lama yang dipandang sebagai penghalang modernisasi, namun di sisi lain mereka belum menemukan sistem baru yang sesuai, yang dapat dijadikan sebagai pedoman dalam menentukan sikap. Kiranya cukup penting untuk mengupayakan nilai/kecerdasan keagamaan Islam dalam proses modernisasi dan perubahan sosial dengan pendekatan yang lebih terbuka, dialogis dan kontekstual.

Secara psikologis, situasi tersebut memiliki pengaruh yang kuat terhadap dinamika kehidupan remaja. Pengaruh kompleksitas kehidupan dewasa ini sudah tampak pada berbagai fenomena remaja yang perlu memperoleh perhatian pendidikan. Fenomena yang tampak akhir-akhir ini, antara lain perkelahian antar pelajar, penyalahgunaan obat dan alkohol, serta berbagai perilaku yang mengarah pada tindakan kriminal. Problem remaja tersebut, merupakan perilaku-perilaku reaktif yang semakin meresahkan jika dikaitkan dengan situasi masa depan remaja yang diperkirakan akan semakin kompleks dan penuh tantangan. Fenomena-fenomena tersebut sangat penting dicegah dan diatasi dengan menanamkan kecerdasan spiritual.

Masa remaja yang sangat potensial, yang dapat berkembang ke arah positif maupun negatif maka intervensi edukatif dalam bentuk pendidikan, bimbingan, maupun pendampingan sangat

\footnotetext{
${ }^{1}$ Abdurrahman Shaleh, Pendidikan Agama dan Pengembangan Watak Bangsa (Jakarta: PT Raja Grafindo, 2006), h. 15.

${ }^{3}$ Al-Qadhi 'Abd. Jabbar, Al-Ma'na fi Abwab al-Tawhid, Jilid XII (Kiro: Muassasah al-Mishriyah alAmmah li al-Nasyr, 2005), h. 13.

${ }^{4}$ Musthofa Rembangy, Pendidikan Transformatif: Pergulatan Kritis Merumuskan Pendidikan di Tengah Pusaran Arus Globalisasi (Yogyakarta: Teras, 2008), h. 3.
} 
diperlukan untuk mengarahkan perkembangan potensi remaja tersebut agar berkembang ke arah yang positif dan produktif. Segala persoalan dan problema yang terjadi pada remaja, sebenarnya berkaitan dengan usia yang anak lalui, dan tidak dapat dilepaskan dari pengaruh lingkungan. Hal itu, suatu faktor penting yang memegang peranan dalam menentukan kehidupan remaja adalah agama. Agama Islam sebagai keyakinan yang dapat menuntun kehidupan manusia, memberikan alternatif dan fondasi dalam melakukan berbagai kegiatan dalam bentuk sikap dan perilaku. Untuk itu dari generasi ke generasi, ajaran Islam selalu diajarkan dalam berbagai konteks pendidikan, baik di masyarakat, keluarga maupun di lembaga pendidikan seperti di sekolah, agar sikap dan perilaku mereka selalu selaras dengan nilai-nilai Islam.

Pendidikan agama Islam berorientasi pada pembentukan pribadi yang berakhlak mulia, tidak hanya memberikan pengetahuan semata, namun juga merealisasikan dalam bentuk kegiatan keagamaan. ${ }^{5}$ Oleh karena itu, untuk mengetahui apakah anak mengamalkan kecerdasan spiritual dalam kesehariannya setelah memperoleh pengetahuan agama dan mengikuti kegiatan keagamaan di sekolah, demikian pula diketahui apakah anak terlibat dalam kegiatan keagamaan di lingkungan masyarakat, atau malah justru sebaliknya.

Bentuk usaha yang dilakukan lembaga pendidikan formal (sekolah) dalam meningkatkan kecerdasan spiritual anak adalah dengan memberikan kegiatan keagamaan. Kegiatan keagamaan ini terdapat program-program yang diusahakan dapat menciptakan dan membangun sikap keberagamaan siswa antara lain: shalat dzuhur berjamaah, shalat dhuha, membaca alQur'an sebelum pembelajaran dimulai, dan perayaan hari besar Islam. Dengan kegiatan keagamaan ini, diharapkan anak dapat mengamalkan kecerdasan spiritual/nilai-nilai yang Islami dalam setiap tindakan serta perbuatan dalam kesehariannya. Selain dapat menambah wawasan dan pengetahuan agamanya, kegiatan keagamaan tersebut merupakan langkah yang tepat karena sebagai langkah awal dalam menanamkan kecerdasan spiritual ke dalam jiwa anak.

\section{HASIL DAN PEMBAHASAN}

\subsection{Penerapan Kegiatan Keagamaan}

\section{Pengertian Penerapan Kegiatan Keagamaan}

Istilah penerapan berdasarkan Kamus Bahasa Indonesia adalah proses, cara, perbuatan menerapkan. ${ }^{6}$ Menurut Mulyasa dalam Suwarno, implementasi (penerapan) merupakan suatu proses penerapan ide, konsep kebijakan atau inovasi dalam suatu tindakan praktis, sehingga memberi dampak baik perubahan pengetahuan, keterampilan maupun nilai dan sikapsedangkan menurut Munir Yusuf dalam Suwarno, implementasi (penerapan) bukan sekadar aktivitas, tetapi suatu kegiatan yang terencana dan dilakukan secara sungguh-sungguh berdasarkan acuan norma tertentu untuk mencapai tujuan kegiatan. ${ }^{7}$ Hal ini dipahami bahwa penerapan merupakan serangkaian upaya untuk mewujudkan konsep yang direncanakan atau yang telah di program untuk mecapai tujuan.

Kegiatan merupakan bagian dari program yang dilaksanakan oleh satu atau lebih unit kerja sebagai bagian dari pencapaian sasaran terukur pada suatu program dan terdiri atas sekumpulan

\footnotetext{
${ }^{5}$ Abuddin Nata, Ilmu Pendidikan Islam dengan Pendekatan Multidisipliner: Normatif Perenialis, Sejarah, Filsafat, Psikologi, Sosiologi, Manajemen, Teknologi, Informasi, Kebudayaaan, Politik, Hukum (Jakarta: Rajawali Pers, 2010), h. 62-63.

${ }^{6}$ Pusat Bahasa, Kamus Bahasa Indonesia (Jakarta: Departemen Pendidikan Nasional, 2008), h. 1056.

${ }^{7}$ Suwarno. Implementasi Pembelajaran Peta Konsep dalam Rangka Meningkatkan Kualitas Mata Pelajaran Ilmu Pengetahuan Alam di Sekolah Dasar. Tesis (Program Pasca Sarjana Universitas Sebelas Maret, 2009), h. 28.
} 
tindakan sedangkan keagamaan berarti hal-hal yang berkaitan dengan agama. ${ }^{8}$ Pengertian kegiatan keagamaan berasal dari dua kata dasar yaitu giat, agama. Giat berarti rajin, bergairah dan bersemangat tentang perbuatan atau usaha. Agama berarti sistem, prinsip kepercayaan kepada Tuhan (Dewa dan sebagainya) dengan ajaran kebaktian dan kewajiban-kewajiban yang bertalian dengan kepercayaan itu ${ }^{9}$ sedangkan pengertian agama menurut Mukti Ali, bahwa memberikan pengertian agama sangat sulit. Hal ini dikarenakan: "pertama, pengalaman agama adalah bersifat subjektif dan batiniah, kedua, orang dalam pembicaraaan agama akan sangat bersemangat dan emosional, ketiga, konsepsi tentang agama akan dipengaruhi oleh tujuan orang memberikan pengertian agama itu. ${ }^{10}$ Deskripsi tersebut menunjukkan bahwa untuk membuat keseragaman konsepsi mengenai agama sangatlah sulit. Hal tersebut tidak terlepas perspektif subjektifitas dalam menjalankan aktifitas keagaman.

Secara etimologi kata agama berarti percaya atau kepercayaan sedangkan menurut terminologi bahwa "agama adalah sebagai hubungan antara mahkluk dengan khaliknya, hubungan ini terwujud dalam sikap batinnya serta tampak pada ibadahnya yang dilakukannya, dan tercermin pula dalam sikap kesehariannya". Secara istilah "agama" berarti peraturan Allah yang diturunkan-Nya kepada manusia dengan perantara Rasul-Nya untuk jadi pedoman bagi manusia dalam melaksanakan kehidupan dan penghidupan di dalam segala aspeknya agar mencapai kejayaan hidup secara lahir dan bathin serta dunia dan akhirat. ${ }^{11}$ Hal ini berarti bahwa agama mengandung unsur-unsur peraturan Allah yang diberikan-Nya kepada manusia, yang berisi pedoman pelaksanaan kehidupan dan penghidupan manusia di dalam segala aspeknya dan bertujuan agar manusia mencapai kejayaan hidup secara lahir dan batin serta dunia dan akhirat.

Dengan demikian, dapat dipahami bahwa penerapan kegiatan keagamaan adalah aktivitas untuk menjalankan suatu program kegiatan keagamaan berdasarkan acuan norma tertentu untuk mencapai tujuan kegiatan secara terukur dan terkendali.

\section{Dasar dan Tujan Kegiatan Keagamaan}

Dasar adalah landasan tempat berpijak agar tegak kokoh berdiri. ${ }^{12}$ Agama Islam adalah agama yang membawa misi agar umatnya menyelanggarakan pendidikan dan pengajaran. ${ }^{13}$ Pelaksanaan pendidikan agama Islam di Indonesia mempunyai dasar-dasar yang cukup kuat yaitu:

a) Dasar Yuridis/Hukum

Dasar pelaksanaan pendidikan agama berasal dari perundang-undangan yang secara tidak langsung dapat menjadi pegangan dalam melaksanakan pendidikan agama di sekolah secara formal, yaitu dasar ideal, yaitu dasar falsafah negara Pancasila, sila pertama : Ketuhanan Yang Maha Esa; dan dasar struktural/konstitusional, yaitu UUD ${ }^{e} 45$ dalam Bab XI pasal 29 ayat 1 dan 2, yang berbunyi: a) Negara berdasarkan atas Ketuhanan Yang Maha Esa; b) Negara menjamin kemerdekaan tiap-tiap penduduk untuk memeluk agama masing-masing dan beribadah menurut agama dan kepercayaan itu.

Berdasarkan bunyi dari pada UUD tersebut, mengandung pengertian bahwa bangsa Indonesia harus beragama. Oleh sebab itu, supaya umat beragama tersebut dapat menunaikan ibadah

\footnotetext{
${ }^{8}$ Zakiyah Darajat, Ilmu Jiwa Agama (Jakarta: PT Bulan Bintang, 2005), h. 63.

${ }^{9}$ Pusat Bahasa, Kamus Bahasa Indonesia, h. 30.

${ }^{10}$ Muhaimin, Kawasan dan Wawasan Studi Islam (Jakarta: Kencana, 2005), h. 29-30.

${ }^{11}$ M. Quraish Shihab, Membumikan al-Qur'an (Bandung: Mizan, 2003), h. 131.

${ }^{12}$ Nur Uhbiyati, Ilmu Pendidikan Islam (Bandung: Pustaka Setia, 2009), h. 19.

${ }^{13}$ Nur Uhbiyati, Ilmu Pendidikan Islam, h. 19.
} 
sesuai dengan agamanya masing-masing maka diperlukan adanya pendidikan agama karena pendidikan agama bagi anak-anak sangat diperlukan sebab tanpa adanya pendidikan agama, akan sulit untuk mewujudkan sila pertama dari Pancasila tersebut.

Urgensi spiritual dalam pendidikan juga dapat dilihat dalam pengertian pendidikan yang tersurat di UU Sisdiknas No.20 tahun 2003 Pasal 1, bahwa pendidikan adalah usaha sadar dan terencana untuk mewujudkan suasana belajar dan proses pembelajaran agar peserta didik secara aktif mengembangkan potensi dirinya untuk memiliki kekuatan spiritual keagamaan, mulia, serta keterampilan yang diperlukan dirinya, masyarakat, bangsa dan negara ${ }^{14}$. Terlihat melalui pengertian tersebut akan pentingnya tujuan pendidikan yaitu mengembangkan kekuatan spiritual keagamaan. Oleh karena itu berarti mengembangkan spiritual, bisa diperoleh melalui kegiatan keagamaan, yang diharapkan nantinya akan terbentuk kekuatan spiritual keagamaan.

b) Al-Qur'an

Umat Islam sebagai suatu umat yang dianugerahkan Tuhan suatu kitab suci al-Qur'an yang letak dengan segala petunjuk yang meliputi seluruh aspek kehidupan dan bersifat universal, sudah barang tentu dasar pendidikan mereka adalah bersumber kepada filsafat kehidupan ynag berdasarkan kepada al-Qur'an.

c) Hadis

Dasar yang kedua selain al-Qur'an adalah sunah rosul, amalan yang dikerjakan oleh Nabi Muhammad saw. Dalam proses perubahan hidup sehari-hari menjadi sumber utama pendidikan Islam karena Allah swt.. menjadikan Muhammad sebagai teladan bagi umatnya. ${ }^{15}$ Dalam visi religius, dalam hal ini terdapat ayat al-Qur'an yang menganjurkan arti penting kegiatan keagamaan Islam, Allah swt. berfirman dalam QS Al-Imran/3: 191, yaitu orang-orang yang mengingat Allah sambil berdiri atau duduk atau dalam keadan berbaring dan mereka memikirkan tentang penciptaan langit dan bumi (seraya berkata): "Ya Tuhan kami, tiadalah Engkau menciptakan ini dengan sia-sia, Maha Suci Engkau, Maka peliharalah kami dari siksa neraka. ${ }^{16}$

Firman Allah di atas menunjukkan betapa pentingnya untuk memiliki/ menerapkan nilai-nilai agama Islam dalam kehidupan sehari-hari seperti selalu mengingat Allah dalam keadaan apapun. Dengan demikian bahwa dasar kegiatan keagamaan berdasarkan hukum, al-Qur'an dan hadist sedangkan tujuan kegiatan keagamaan untuk meningkatkan keimanan, pemahaman, penghayatan kepada Allah swt., serta berakhlak mulia dalam kehidupan pribadi, bermasyarakat, berbangsa dan bernegara.

\section{Bentuk-bentuk kegiatan Keagamaan}

Menurut Zuhairini, praktek keagamaan berasal dari bahasa Indonesia, "praktek dan agama". Yang dimaksud dengan praktek adalah pelaksanaan secara nyata apa yang disebut dengan teori sedangkan yang dimaksud dengan agama adalah sistem kepercayaan kepada Tuhan dengan ajaran kebaktian dan kewajiban-kewajiban yang berkaitan dengan kepercayaan itu. Selain itu, materi program kegiatan keagamaan dapat mencakup ruang lingkup yang luas dalam keseluruhan ajaran Islam dalam garis besarnya, materi kegiatan keagamaan disekolah dapat dibedakan menjadi tiga bidang pokok, yaitu keimanan (tauhid), keislaman (syari'ah) dan ihsan 2006), h. 50 .

${ }^{14}$ Undang-Undang RI No.20 Tahun 2003 Tentang Sistem Pendidikan Nasional (Jakarta: Asa Mandiri,

${ }^{15}$ Ramayulis, Ilmu Pendidikan Islam (Jakarta: Kalam Mulia, 2002), h. 24-25.

${ }^{16}$ Departemen Agama RI, Al-Qur'an \& Terjemahnya (Jakarta: Yayasan Penyelenggara Penerjemah/Penafsir Al-Qur'an Revisi Terjemah oleh Lajnah Pentashih Mushaf Al-Qur'an, 2007), h. 130. 
(akhlak). ${ }^{17}$ Dari ketiga pokok kegiatan keagamaan tersebut, menunjukkan bahwa pondasi dalam kegiatan keagamaan tidak daapat terlepas dari ketiga pondasi tersebut sebagai indicator dalam aktifitas keagamaan. Misalnya mengenai tauhid, tidak seorang pun yang dapat mengatakan tidak ber-tuhan walaupun sedetik, begitu juga dengan akhlak. Hal tersebut menunjukkan bahwa ketiga pondasi tersebut tidak dapat dibatasi oleh ruang dan waktu serta dari ketiga bidang pokok tersebut melahirkan cabang-cabang kegiatan keagamaan yang diimplementasikan dalam kehidupan sehari-hari.

Dalam buku Petunjuk Pelaksanaan Pendidikan Agama Islam disebutkan contoh kegiatan keagamaan seperti: musabaqoh tilawatil Qur'an, ceramah pengajian mingguan, peringatan hari besar, kunjungan ke museum, ziarah ke makam Islam, seni kaligrafi, penyelenggaraan shalat jum'at, shalat tarawih, dan cinta alam. ${ }^{18}$ Selain bentuk-bentuk kegiatan keagamaan di atas, menurut buku yang ditulis oleh Amin Syukur yang berjudul Pengantar Studi Islam, bentukbentuk kegiatan keagamaan, sebagai berikut:

a) Doa bersama sebelum memulai dan sesudah selesai kegiatan belajar mengajar;

b) Tadarus Alquran (secara bersama-sama atau bergantian) selama 15-20 menit sebelum waktu belajar jam pertama dimulai. Tadarus Alquran dipimpin oleh guru yang mengajar pada jam pertama;

c) Shalat Dzuhur berjamaah dan kultum (kuliah tujuh menit), atau pengajian/bimbingan keagamaan secara berkala;

d) Mengisi peringatan hari-hari besar keagamaan dengan kegiatan yang menunjang internalisasi nilai-nilai agama, dan menambah ketaatan beribadah;

e) Mengintensifkan praktik ibadah, baik ibadah mahdhah maupun ibadah sosial;

f) yang relevan dengan nilai-nilai agama/ dalil nash al-Qur'an atau hadits rasulullah saw;

g) Mengadakan pengajian kitab di luar waktu terjadwal;

h) Menciptakan hubungan ukhuwah Islamiyah dan kekeluargaan antara guru, pegawai, siswa, dan masyarakat sekitar;

i) Mengembangkan semangat belajar, cinta tanah air, dan mengagungkan kemuliaan agamanya;

j) Menjaga ketertiban, kebersihan dan terlaksananya amal shaleh dalam kehidupan yang sarwa ibadah di kalangan siswa, karyawan, guru, dan masyarakat lingkungan sekolah. ${ }^{19}$

Berdasarkan dari deskripsi di atas, bahwa filosofi bentuk-bentuk penerapan kegiatan keagamaan sesungguhnya membumikan rukun Islam yang bertujuan untuk meningkatkan keimanan, pemahaman, penghayatan dan pengalaman spiritual di bidang keagamaan kepada anak sesuai dengan perintah agama untuk mencapai tujuan agama dan sistem pendidikan nasional.

\subsection{Kecerdasan Spiritual}

\section{Pengertian Kecerdasan Spiritual}

Kecerdasan spiritual adalah kecerdasan/nilai luhur yang ditransfer dan diadopsi ke dalam diri. Jadi, internalisasi kecerdasan spiritual adalah suatu proses memasukan nilai-nilai agama secara penuh ke dalam hati, sehingga ruh dan jiwa bergerak berdasarkan ajaran agama Islam.

\footnotetext{
${ }^{17}$ Zuhairini, Metodik Khusus Pendidikan Islam (Surabaya: Usaha Nasional, 2010 ), h. 58.

${ }^{18}$ Kemendiknas, Petunjuk Pelaksanaan Pendidikan Agama Islam (Jakarta: Kemendiknas, 2010), h. 13.

${ }^{19}$ Abdul Rachman Shaleh, Madrasah dan Pendidikan Anak Bangsa: Visi, Misi,dan Aksi (Jakarta: PT. Raja Grafindo Persada, 2005), h. 170.
} 
Internalisasi kecerdasan spiritual itu terjadi melalui pemahaman ajaran agama secara utuh, dan diteruskan dengan kesadaran akan pentingnya agama Islam, serta ditemukannya posibilitas untuk merealisasikannya dalam kehidupan nyata. ${ }^{20} \mathrm{Hal}$ ini berarti bahwa kecerdasan spiritual adalah sifat-sifat atau hal-hal yang berguna bagi kemanusiaan. Kecerdasan spiritual adalah sesuatu yang dapat dijadikan sasaran untuk mencapai tujuan yang menjadi sifat keseluruhan tatanan yang terdiri dari dua atau lebih dari komponen yang satu sama lainnya saling mempengaruhi atau bekerja dalam kesatuan/keterpaduan yang bulat dan berorientasi kepada nilai dan moralitas islami.

\section{Spritual dalam Perspektif Islam}

Membicarakan spiritual dalam pandangan Islam, spirit dalam bahasa Arabnya ruh dan spiritual (ruhaniyah), tidak pernah dilepaskan dengan aspek Ketuhanan. Sebagaimana pendapat Taufiq Pasiak bahwa membicarakan spiritualitas berarti membicarakan tentang Tuhan. ${ }^{21}$ Pendapat Taufiq tersebut, tidak terlepas dari filosofi kehadiran agama pada kehidupan alam semesta dan penciptaan makhluk hidup termasuk manusia, yakni untuk menyembah kepada Tuhan sebagai sebab yang tidak bersebab (causa prima) atau sebagai sang arsitektur alam semesta.

Spiritual adalah suatu dimensi yang terkesan maha luas, tak tersentuh, jauh diluar sana karena tuhan dalam pengertian Yang Maha Kuasa, benda dalam sistem yang metafisis dan transenden, sehingga sekaligus meniscayakan nuansa mistis dan suprarasional. ${ }^{22}$ Hal tersebut, menunjukkan bahwa esensi persoalan spiritual adalah terkait dengan alam metafisik yang bersumber dari dalam diri manusia yang tidak dapat dijangkau oleh alam fisika (panca indera). Konsep tersebut senada dengan pendapat para pemikir filsafat Islam terkait dengan definisi spiritual.

Sayyed Hossein Nasr mendefinisikan spiritual sebagai "pengalaman yang suci". ${ }^{23}$ Pemaknaan ini kemudian diintroduksi oleh seluruh pemikir agama (spiritualis) dalam "pemahaman makna keyakinan dalam konteks sosial mereka". Jadi tegasnya, spiritual diasumsikan bukan dalam pengertian diskursifnya, at home atau in side, melainkan terefleksikan dalam perilaku sosialnya. Ini sekaligus menunjukkan bahwa segala perilaku sosial manusia juga diwarnai oleh "pengalaman yang suci" dan itulah spiritualitasnya.

Spiritualisme di dalam Islam adalah spiritualisme yang bervisi langit, transenden, dan spiritual. ${ }^{24}$ Hakikat spiritualitas adalah pandangan pribadi dan perilaku yang mengekspresikan rasa keterkaitan ke dimensi transendental (Yang Maha Tinggi) atau untuk sesuatu yang lebih besar dari diri sehingga mengerti arti dan tujuan hidup.

Dengan demikian, dapat dipahami bahwa spiritual dalam perspektif Islam yaitu senantiasa berkaitan secara langsung dengan realitas Ilahi, Tuhan Yang Maha Esa (tauhid). Spiritualitas bukan sesuatu yang asing lagi bagi manusia, karena merupakan inti (core) kemanusiaan itu sendiri. Spiritualitas agama (religious spirituality) berkenaan dengan kualitas mental (kesadaran), perasaan, moralitas, dan nilai-nilai luhur lainnya yang bersumber dari ajaran agama. Spiritualitas agama bersifat Ilahiah, bukan bersifat humanistik lantaran berasal dari Tuhan. Spiritualisme dalam agama Islam adalah Islam itu sendiri, yang mempresentasikan

\footnotetext{
${ }^{20}$ Muhammad Alim, Pendidikan Agama Islam Upaya Pembentukan Pemikiran dan Kepribadian Muslim (Bandung: PT. Remaja Rosdakarya, 2006), h. 10.

${ }^{21}$ Taufiq Pasiak, Antara "Tuhan Empirik" dan Kesehatan Spiritual (Yogykarta: C-NET UIN Sunan Kalijaga, 2012), h. 8.

${ }^{22}$ Yahya Jaya, Spiritualisasi Islam Dalam Menumbuhkembangkan Kepribadian dan Kesehatan Mental (Jakarta: Ruhama, 2011), h. 64.

${ }^{23}$ Sayyed Hossein Nasr, Antara Tuhan, Manusia dalam Alam; Jembatan Filosofis dan Religius Menuju Puncak Spritual, terjemahan oleh Ali Noer Zaman (Cet. Ke-1 Yogyakarta: IRCisoD, 2003), h. 7.

${ }^{24}$ Muhammad Muhyidin, Manajemen ESQ Power (Cet 3; Jogjakarta: DIVA Press, 2007), h. 386.
} 
ajaran-ajaran yang bersifat holistik dan integral. Spiritual merupakan kebenaran mutlak, perwujudan kedekatan kepada Yang Maha Pencipta berupa keimanan, ketakwaan, ketawadhu'an, kecerdasan, keikhlasan, pengabdian dan penyembahan. Spiritualitas seorang muslim sejati yakni, perwujudan dari visi dan nilai-nilai keberIslaman yang diajarkan oleh Rasulullah saw dari Allah swt.

\section{Aspek-aspek Kecerdasan Spiritual}

Menurut Ary Ginanjar Agustian dalam buku best sellernya Emotional Spiritual Quotient menyebutkan bahwa kecerdasan spiritual adalah kemampuan untuk memberi makna spiritual terhadap pemikiran, setiap perilaku dan kegiatan, melalui langkah-langkah dan pemikiran yang bersifat fitrah, menuju manusia yang seutuhnya (hanif) dan memiliki pola pemikiran tauhid (integralistik), serta berprinsip "hanya karena Allah". Selanjutnya Gynanjar menegaskan dengan mengutip pernyataan Danar Zohar dan Ian Marshall bahwa kecerdasan spiritual (SQ) adalah kecerdasan tertinggi ${ }^{25}$ sedangkan Toto Tasmara menyebut kecerdasan spiritual sebagai kecerdasan ruhaniah (Transcendental Intelligence). Toto menjelaskan bahwa kecerdasan spiritual adalah kemampuan seseorang untuk mendengarkan hati nuraninya, baik buruk dan rasa moral dalam caranya menempatkan diri dalam pergaulan. ${ }^{26} \mathrm{Hal}$ ini membuktikan bahwa keceradasan spiritual merupakan kecerdasan yang bersumber oleh alam internal manusia. Misalnya, alam qalbu dan insting manusia yang tidak terlepas dengan bantuan cahaya metafisik yakni cahaya Ilahi.

Menurut Abdullah Nashih Ulwan, aspek-aspek kecerdasan spiritual meliputi hal-hal sebagai berikut: melakukan berbagai zikir, wirid dan doa-doa dengan memperhatikan adab-adabnya; Tarbiyah ruhiyah secara alami, yaitu: melaksanakan berbagai kewajiban dengan menghadirkan hati, memperbanyak melakukan berbagai ibadah sunnah, Senantiasa melaksanakan amar ma'ruf nahi munkar, berusaha dapat mencapai kedudukan ihsan, melakukan berbagai aktivitas di jalan Allah swt., mengadakan berbagai pertemuan malam untuk ibadah, dan menziarahi kubur; dan komitmen untuk menyesuaikan diri dengan spesifikasi orang-orang mukmin, yaitu memiliki perasaan yang kuat akan keberadaan Allah, merasakan adanya pengawasan Allah terhadap diri sendiri, mendekatkan diri kepada Allah dengan melakukan berbagai ibadah nafilah (sunnah), mendekati Allah dengan mencintai manusia dan mencintai kebaikan bagi mereka, mencintai Allah dan percaya kepada-Nya serta percaya pada kebaikan-Nya dan pengabulan-Nya, serta rela atas qadha dan qadar Allah. ${ }^{27}$

Pendapat Abdullah Nashih Ulwan di atas, membuktikan uraian sebelumnya, bahwa aspekaspek kecerdasan spiritual tidak terlepas dengan cahaya metafisik yakni cahaya Ilahi yang tidak dapat dijangkau dengan alam fisika (indera). Akan tetapi, merupakan domain alam metafisik manusia. Misalnya, sifat sabar. Hal tersebut tidak dapat dijangkau melalui indera. Akan tetapi, dapat dijangkau melalui aspek ruhaniah.

Selain aspek-aspek kecerdasan spiritual di atas, Menurut Danah Zohar dan Ian Marshal aspekaspek kecerdasan spiritual itu adalah: kemampuan bersikap fleksibel, dapat menempatkan diri dan menerima pendapat orang lain secara terbuka; tingkat Kesadaran diri yang tinggi, tingkat kesadaran diri yang tinggi seperti kemampuan autocritism dan mengerti tujuan serta visi hidupnya; kemampuan untuk menghadapi dan memanfaatkan penderitaan, kemampuan

${ }^{25}$ Ary Ginanjar Agustian, Rahasia Sukses Membangun Kecerdasan Emsi dan Spiritual:EQ (Emotuonal, Spiritual dan Quotient) (Jakarta: Penerbit Agra, 2005), h. 47.

${ }^{26}$ Toto Asmara, Kecerdasan Ruhaniyah (Trancendental Intelligence) Membentuk Kepribadian yang Bertanggung Jawab, Profesioanl dan Berakhlak (Jakarta: Gema Insani Press, 2001), h. 23.

${ }^{27}$ Abdullah Nashih Ulwan, Tarbiyah Ruhiyah, (Terj.), Ajid Muslim (Cet. 10; Jakarta: Rabbani Press, 2010), h. 72 . 
seseorang dalam menghadapi penderitaan dan menjadikan penderitaan yang dialami sebagai motivasi untuk mendapatkan kehidupan yang lebih baik dikemudian hari serta tetap tersenyum dan bersikap tenang; dan kemampuan untuk menghadapi dan melampaui rasa sakit, kemampuan seseorang dimana di saat dia mengalami sakit, dia akan menyadari keterbatasan dirinya, dan menjadi lebih dekat dengan Tuhan dan yakin bahwa hanya Tuhan yang akan memberikan kesembuhan serta kemampuan untuk menghadapi dan melampaui rasa sakit ini ditandai juga dengan munculnya sikap ikhlas dan pemaaf; kualitas hidup yang diilhami oleh visi dan nilai-nilai, kualitas hidup seseorang yang didasarkan pada tujuan hidup yang pasti dan berpegang pada nilai-nilai yang mampu mendorong untuk mencapai tujuan tersebut, seperti prinsip dan pegangan hidup dan berpijak pada kebenaran; keengganan untuk menyebabkan kerugian yang tidak perlu, seseorang yang memiliki kecerdasan spiritual yang tinggi mengetahui bahwa ketika dia merugikan orang lain, maka berarti dia merugikan dirinya sendiri sehingga mereka enggan untuk melakukan kerugian yang tidak perlu. Keengganan untuk menyebabkan kerugian yang tidak perlu misalnya menunda pekerjaan dan cenderung berpikir sebelum bertindak; berpikir secara holistik, kecenderungan untuk melihat keterkaitan antara berbagai hal atau memiliki pandangan yang holistik yakni mampu untuk berpikir secara logis dan berlaku sesuai dengan norma sosial; kecenderungan untuk bertanya mengapa dan bagaimana jika untuk mencari jawaban-jawaban yang mendasar, kecenderungan menanyakan "mengapa" atau "bagaimana" jika akan mencari jawaban-jawaban yang mendasar dan memiliki kemampuan untuk berimajinasi serta memiliki rasa ingin tahu yang tinggi; dan menjadi pribadi mandiri, mudah untuk bekerja melawan konvensi (adat dan kebiasaan sosial), seperti mau memberi dan tidak mau menerima dan tidak tergantung dengan orang lain. ${ }^{28}$

Berdasarkan beberapa aspek di atas, dapat dipahami bahwa seseorang yang cerdas secara ruhaniah/spiritualnya adalah mampu merefleksikan rasa cintanya dalam pengorbanan untuk mengubah dunia dengan akal budaya dan peradabannya, sehingga batin dirinya yang merindukan Allah swt. akan tampak dan bukti dirinya mengambil tempat di dunia sebagai rahmatan lil 'alamin. Inilah bentuk mahabbah yang paling sejati kepada Allah swt.. sebagaimana sikap dan perilaku akhlak rasulullah saw. yang dicontoh dalam kehidupan seharihari. Orang yang cerdas secara ruhaniah perlu memiliki karakteristik yang harus dipenuhi, sebagai landasan atau teori dalam kecerdasan ruhaniah atau spiritual.

\section{Fungsi Kecerdasan Spritual}

Menurut Udik Abdullah, manusia yang memiliki spiritual yang baik akan memiliki hubungan yang kuat dengan Allah swt.. ${ }^{29}$ Hal ini dapat dipahami bahwa dengan adanya kecerdasan spiritual akan berdampak pula kepada kepandaian dalam berinteraksi dengan manusia karena dibantu oleh Allah yaitu hati manusia dijadikan cenderung kepada-Nya.

Kecerdasan spiritual menurut Danar Zohar dan Ian Marshall merupakan landasan yang diperlukan untuk memfungsikan IQ dan EQ secara efektif dan kecerdasan spiritual ini adalah kecerdasan tertinggi manusia. ${ }^{30}$ Kecerdasan spiritual membimbing manusia untuk meraih kebahagiaan hidup hakiki dan membimbing manusia untuk mendapatkan kedamaian selanjutnya menurut Ary Ginanjar menggunakan kecerdasan spiritual dalam pengambilan keputusan cenderung akan melahirkan keputusan yang terbaik, yaitu keputusan spiritual. ${ }^{31}$

\footnotetext{
${ }^{28}$ Danah Zohar dan Ian Marshall, SQ-Kecerdasan Spiritual (Bandung: Mizan, 2007), h. 14.

${ }^{29}$ Udik Abdullah, Meledakkan IESQ dengan Langkah Taqwa dan Tawakal (Jakarta: Zikrul Hakim, 2005), h. 181 .

${ }^{30}$ Danah Zohar dan Ian Marshall, SQ-Kecerdasan, h. 20.

${ }^{31}$ Ary Ginanjar Agustian, Rahasia Sukses Membangun Kecerdasan Emosi dan Spiritual:EQ (Emotuonal, Spiritual dan Quotient), h. 100.
} 
Keputusan spiritual itu adalah keputusan yang diambil dengan mengedepankan sifat-sifat ilahiah dan menuju kesabaran mengikuti Allah as-Sabur atau tetap mengikuti suara hati unuk memberi atau taqarrub kepada al-Wahhab dan tetap menyayangi menuju sifat Allah ar-Rahim.

Berdasarkan uraian tentang fungsi kecerdasan spiritual di atas, dapat dipahami bahwa hakikat yang sesungguhnya mengenai fungsi dari kecerdasan spiritual adalah membimbing seseorang agar mendidik hati menjadi benar dan selalu melakukan kegiatan sehari-hari sesuai dengan tuntunan yang sudah disampaikan oleh Allah swt.

\section{Faktor-Faktor yang Mempengaruhi Kecerdasan Spritual}

Menurut Ary Ginanjar, ada tiga faktor yang mempengaruhi kecerdasan spiritual, yaitu:

a) God-Spot (Titik Tuhan)

Seorang ahli syaraf dari California University yaitu Prof. V.S. Ramachandran telah berhasil mengidentifikasi God-Spot dalam otak manusia yang merupakan pusat spiritual terletak antara jaringan saraf dan otak. Dalam penelitiannya Ramachandra menemukan adanya bagian dalam otak, yaitu lobus temporal yang meningkat ketika pengalaman religius atau spiritual berlangsung, dan menyebutnya sebagai titik Tuhan atau God-Spot. Titik Tuhan memainkan peran biologis yang menentukan dalam pengalaman spiritual. ${ }^{32} \mathrm{Hal}$ tersebut membuktikan, bahwa pengaruh metafisik sangat signifikan memiliki implikasi dalam membangun kecerdasan spiritual manusia.

b) Potensi Qalbu

Menggali potensi qalbu, secara klasik sering dihubungkan dengan 'polemos' amarah, 'eros' cinta dan 'logos' pengetahuan. Padahal dimensi qalbu tidak hanya mencakup atau dicakup dengan pembatasan katagori yang pasti. Menangkap dan memahami pengertiannya secara utuh adalah kemustahilan. Itu hanyalah sebagai asumsi dari proses perenungan yang sangat personal karena di dalam qalbu terdapat potensi yang sangat multi dimensional. Diantaranya adalah sebagai berikut:

1) Fu'ad merupakan potensi qalbu yang sangat berkaitan dengan indrawi, mengolah informasi yang sering dilambangkan berada dalam otak manusia (fungsi rasional kognitif). Fu'ad memberi ruang untuk akal, berpikir, bertafakur, memilih dan memilah seluruh data yang masuk dalam qalbu. Sehingga lahirlah ilmu pengetahuan yang bermuatan moral. Pengawas setia sang fu'ad adalah akal, zikir, pendengaran dan penglihatan yang secara nyata yang sistimatis diuraikan dalam al-Qur'an.

2) Shadr yang berperan untuk merasakan dan menghayati atau mempunyai fungsi emosi (marah, benci, cinta, indah, efektif). Shadr adalah dinding hati yang menerima limpahan cahaya keindahan, sehingga mampu menerjemahkan segala sesuatu serumit apapun menjadi indah dari karyanya. Berbeda dengan Fu'ad yang berorientasi ke depan. Shadr memandang pada masa lalu, kesejarahan, serta nostalgia melalui rasa, pengalaman dan keberhasilan sebagai cermin. Dengan kompetensinya untuk melihat dunia masa lalu, manusia mempunyai kemampuan untuk menimbang, membanding dan menghasilkan kearifan.

3) Hawaa merupakan potensi qalbu yang mengarahkan kemauan. Di dalamnya ada ambisi, kekuasaan, pengaruh, dan keinginan untuk mendunia. Potensi hawaa cendrung untuk membumi dan merasakan nikmat dunia yang bersifat fana. Potensi hawaa selalu ingin membawa pada sikap-sikap yang rendah, menggoda, merayu dan menyesatkan tetapi sekaligus memikat. Walaupun cahaya di dalam qalbu pada fitrahnya selalu benderang,

\footnotetext{
${ }^{32}$ Ary Ginanjar Agustian, Rahasia Sukses Membangun Kecerdasan Emosi dan Spiritual ESQ Berdasarkan 6 Rukun Iman dan 5 Rukun Islam, h.165.
} 
tetapi karena manusia mempunyai hawaa ini, maka seluruh qalbu bisa rusak binasa karena keterpikatan dan bisikan yang dihembuskan setan kedalam potensi seluruh hawaa. ${ }^{33}$ Hal ini berarti, membangun kecerdasan spiritual melalui potensi qalbu ditentukan dari energi positif dan bantuan cahaya ilahi dalam qalbu setiap manusia, karena qalbu merupakan cermin dari setiap kebaikan dan keburukan. Jika qalbu manusia menjadi kotor dengan hal-hal yang buruk, maka realitas fisik atau realitas empiris juga menjadi buruk.

c) Nafas dan Kehendak Nafsu

Nafs adalah muara yang menampung hasil olah fu'ad, shadr, dan hawaa yang kemudian menampakan dirinya dalam bentuk perilaku nyata di hadapan manusia lainnya. Nafs merupakan keseluruhan atau totalitas dari diri manusia itu sendiri. Apabila nafs mendapatkan pencerahan dari cahaya qalbu, maka dinding biliknya benderang memantulkan binar-binar kemuliaan. Jiwa nafs yang melangit, merindu, dan menemukan wajah Tuhan akan stabil merasakan kehangatan cinta ilahi. ${ }^{34}$ Hal ini berarti membuktikan uaraian sebelumnya bahwa qalbu manusia merupakan cermin cahaya ilahi sebagaimana pada filsafat iluminasi yang mengasumsikan bahwa realitas merupakan pantulan dari cahaya qalbu.

Dengan demikian, berdasarkan beberapa hal di atas dapat dipahami bahwa faktor-faktor yang mempengaruhi kecerdasan spiritual sesungguhnya berdasarkan pengetahuan yang bersifat immaterial dan non-fisika yang potensinya berasal dari dalam diri manusia dan yang untuk peningkatan kecerdasan spritual tergantung dari potensi cahaya ilahi yang diraih oleh manusia melalui pendekatan secara intensif melalui kegiatan keagamaan.

\section{SIMPULAN}

Mengembangkan kecerdasan spiritual anak dibutuhkan kiat-kiat tersendiri diantaranya yaitu membaca kitab suci bersama-sama dan menjelaskan maknanya dalam kehidupan sehingga tadarus al-Qur'an sangat berpengaruh terhadap kecerdasan spiritual. Selain itu, kecerdasan spiritual mendorong anak untuk melakukan hal yang lebih baik dalam menyelesaikan masalah atau mengontrol diri dalam berinteraksi atau berkomunikasi dengan orang lain karena seseorang yang sedang mengalami masalah memiliki hati yang gundah maka dibutuhkan cara untuk menenangkan yaitu salah satunya dengan tadarus al-Qur'an karena tadarus al-Qur'an merupakan kegiatan keagamaan yang mampu menjadi pengobat dan penawar jiwa yang sedang gundah dan gelisah.

Dengan demikian, dapat dipahami bahwa kegiatan keagamaan adalah sebagai sistem kepercayaan dan peribadatan dimana seseorang bisa mengungkapkan dengan jelas secara lahiriah mengenai spiritualitasnya. Sehingga, seseorang yang memiliki agama yang baik atau hubungan yang kuat dengan Allah swt., akan memiliki kecerdasan spiritual yang baik pula sehingga akan berdampak pula kepada kepandaian orang tersebut dalam berinteraksi dengan manusia, karena dibantu oleh Allah yaitu hati manusia dijadikan cenderung kepada-Nya. Untuk itu, lingkungan sekolah yang merupakan lembaga formal juga mempengaruhi kecerdasan spiritual anak karena selain memperoleh pengetahuan, anak juga harus diberi contoh atau pemahaman akan perbuatan atau nilai. Jika guru memberi nilai kehidupan (ajaran keagamaan)

${ }^{33}$ Ary Ginanjar Agustian, Rahasia Sukses Membangun Kecerdasan Emosi dan Spiritual ESQ Berdasarkan 6 Rukun Iman dan 5 Rukun Islam, h. 102-103.

${ }^{34}$ Ary Ginanjar Agustian, Rahasia Sukses Membangun Kecerdasan Emosi dan Spiritual ESQ Berdasarkan 6 Rukun Iman dan 5 Rukun Islam, h. 109-110. 
yang baik untuk anak, maka akan membuat kecerdasan spiritual anak akan baik pula sehingga diharapkan anak mampu memaknai hidupnya dengan lebih baik.

\section{DAFTAR PUSTAKA}

Abd. Jabbar, Al-Qadhi. Al-Ma'na fi Abwab al-Tawhid, Jilid XII. Kiro: Muassasah al-Mishriyah al-Ammah li al-Nasyr, 2005.

Abdullah, Udik. Meledakkan IESQ dengan Langkah Taqwa dan Tawakal. Jakarta: Zikrul Hakim, 2005.

Agustian, Ary Ginanjar Rahasia Sukses Membangun Kecerdasan Em $\neg$ si dan Spiritual:EQ (Emotuonal, Spiritual dan Quotient). Jakarta: Penerbit Agra, 2005.

Alim. Muhammad. Pendidikan Agama Islam Upaya Pembentukan Pemikiran dan Kepribadian Muslim. Bandung: PT. Remaja Rosdakarya, 2006.

Asmara, Toto. Kecerdasan Ruhaniyah (Trancendental Intelligence) Membentuk Kepribadian yang Bertanggung Jawab, Profesioanl dan Berakhla. Jakarta: Gema Insani Press, 2001.

Darajat, Zakiyah. Ilmu Jiwa Agama. Jakarta: PT Bulan Bintang, 2005.

Departemen Agama RI, Al-Qur'an \& Terjemahnya. Jakarta: Yayasan Penyelenggara Penerjemah/Penafsir Al-Qur'an Revisi Terjemah oleh Lajnah Pentashih Mushaf AlQur'an, 2007.

Hossein Nasr, Sayyed. Antara Tuhan, Manusia dalam Alam; Jembatan Filosofis dan Religius Menuju Puncak Spritual, terjemahan oleh Ali Noer Zaman. Cet. Ke-1 Yogyakarta: IRCisoD, 2003.

Jaya,Yahya. Spiritualisasi Islam Dalam Menumbuhkembangkan Kepribadian dan Kesehatan Mental. Jakarta: Ruhama, 2011.

Kemendiknas. Petunjuk Pelaksanaan Pendidikan Agama Islam. Jakarta: Kemendiknas, 2010.

Muhaimin. Kawasan dan Wawasan Studi Islam. Jakarta: Kencana, 2005.

Muhyidin, Muhammad. Manajemen ESQ Power. Cet 3; Jogjakarta: DIVA Press, 2007.

Nata, Abuddin. Ilmu Pendidikan Islam dengan Pendekatan Multidisipliner: Normatif Perenialis, Sejarah, Filsafat, Psikologi, Sosiologi, Manajemen, Teknologi, Informasi, Kebudayaaan, Politik, Hukum. Jakarta: Rajawali Pers, 2010.

Pasiak, Taufiq. Antara "Tuhan Empirik" dan Kesehatan Spiritual. Yogy $\neg$ karta: C-NET UIN Sunan Kalijaga, 2012.

Pusat Bahasa. Kamus Bahasa Indonesia. Jakarta: Departemen Pendidikan Nasional, 2008.

Ramayulis. Ilmu Pendidikan Islam. Jakarta: Kalam Mulia, 2002.

Rembangy. Musthofa. Pendidikan Transformatif: Pergulatan Kritis Merumuskan Pendidikan di Tengah Pusaran Arus Globalisasi. Yogyakarta: Teras, 2008.

Shaleh, Abdul Rachman. Madrasah dan Pendidikan Anak Bangsa: Visi, Misi,dan Aksi. Jakarta: PT. Raja Grafindo Persada, 2005.

Shaleh, Abdurrahman. Pendidikan Agama dan Pengembangan Watak Bangsa. Jakarta: PT Raja Grafindo, 2006.

Shihab, M. Quraish. Membumikan al-Qur'an. Bandung: Mizan, 2003.

Suwarno. Implementasi Pembelajaran Peta Konsep dalam Rangka Meningkatkan Kualitas Mata Pelajaran Ilmu Pengetahuan Alam di Sekolah Dasar. Tesis. Program Pasca Sarjana Universitas Sebelas Maret, 2009.

Uhbiyati, Nur. Ilmu Pendidikan Islam. Bandung: Pustaka Setia, 2009. 
Ulwan, Abdullah Nashih. Tarbiyah Ruhiyah, (Terj.), Ajid Muslim. Cet. 10; Jakarta: Rabbani Press, 2010.

Undang-Undang RI No.20 Tahun 2003 Tentang Sistem Pendidikan Nasional. Jakarta: Asa Mandiri, 2006.

Zohar, Danah dan Ian Marshall. SQ-Kecerdasan Spiritual. Bandung: Mizan, 2007.

Zuhairini. Metodik Khusus Pendidikan Islam. Surabaya: Usaha Nasional, 2010. 